Author's postprint:

SOLSONA, Montse; FERRER, Laia; SIMÓ-NOGUERA, Carles; SPIJKER, Jeroen (2020) "Divorce and Gendered Family $(\mathrm{Re})$ Configurations in a Sample of Employed and Higher Educated Mothers and Fathers". Journal of Divorce \& Remarriage, 61 (7): 463-486 (ISSN: 1050-2556). https://doi.org/10.1080/10502556.2020.1768492 


\section{Divorce and gendered family (re)configurations in a sample of employed and higher educated mothers and fathers}

Montse Solsona ${ }^{\mathrm{a}, \mathrm{b}}$ Orcid.org/0000-0002-5613-672X

Laia Ferrer ${ }^{\mathrm{c}}$ Orcid.org/0000-0002-5860-9105

Carles Simó-Noguera ${ }^{\mathrm{d}}$ Orcid.org/0000-0002-3569-1804

Jeroen Spijker ${ }^{\text {a* }}$ Orcid.org/0000-0002-3957-9553

${ }^{a}$ Centre d'Estudis Demogràfics, Bellaterra, Spain

${ }^{b}$ Department of Geography, Universitat Autonoma de Barcelona, Bellaterra, Spain

c Institut d'Investigacio Germans Trias i Pujol (IGTP), Barcelona, Spain

${ }^{d}$ Department of Sociology and Social Anthropology, Universitat de Valencia, Valencia, Spain

* Corresponding author: Centre d'Estudis Demogràfics, Edifici E-2, Carrer de Ca n'Altayò, Campus de la UAB, 08193 Bellaterra, Spain. Tel. +34 935813060. Email: jspijker@ced.uab.es.

Acknowledgements :We are grateful to Cristina Brullet for having assisted us in the study design, to the 26 interviewees for their time and openness and Alex Massardo, Mireia Baylina, Iñaki Permanyer and Ana Maria Goldani for their useful comments and corrections on the paper.

Funding: This work was supported by the Spanish Ministry of Science, Innovation and Universities through a grant to study "Joint custody after union breakup. Which contexts favour this emerging paradigm?" (Ref.: CSO2016-78715-R), as well as the "Ramón y Cajal" programme (Ref.: RYC-2013-14851). 


\section{Divorce and gendered family (re)configurations in a sample of employed and higher educated mothers and fathers}

From 26 semi-structured interviews conducted in Spain we examine how motherhood and fatherhood is redefined and how family configurations are reshaped after a divorce or separation. The existence of common children in our sample meant that their original nuclear family never completely dissolved as the meaning of families became broader and more complex. Family was not restricted to a specific home, those who shared a home weren't necessarily united by family ties, nor did living alone necessarily mean a lack of family, stable relationships, or strong emotional ties. Gender transcended all divorce-related issues although for all respondents post-divorce mothering/fathering was also vivid and related to the mothering/fathering before the break-up.

Keywords: gender; family configurations; mothering/fathering, post-divorce; narrative; Spain 


\section{Introduction}

This study aims to analyze the different paths that appeared after a union breakdown and the reasoning process attached to it. It uses a qualitative narrative approach by integrating narratives on family ties, emotional needs and individuals' explanations of the process: decisions, fears and individual eventualities. Specifically, this paper examines two issues from 26 semi-structured interviews conducted in 2008 in the four biggest metropolitan areas of Spain: how motherhood and fatherhood is redefined and family configurations are reshaped after a divorce or separation. Information concerning specific dimensions of each issue is obtained, including incidence of conflict and determinant factors (triggers) of the union dissolution; how motherhood/fatherhood was lived before and after the break-up, including the centrality of children and new relationships/parenthood; and thirdly, what constitutes the post-divorce family, links and configurations. A gender perspective is taken as perceptions related to an individual's behavior and that of the ex-partner play an important part in the redefinition of parenthood and family configurations.

In Spain, after the end of the Franco dictatorship (1975), rapid social changes took place that shaped the persons interviewed in our study, distinguishing them from both older and more recent generations. This fascist dictatorship was characterized by control of the church in family law -based on the "natural, religious and historical legal authority that was given to the husband' - that granted unequal rights in function of sex (Iglesias de Ussel, 1998; Moran, 1995). Spain was not just a bread-winner society, women even needed marital permission for a job, to start an own business, to open a bank account, to initiate legal proceedings, to buy and sell goods, or to obtain a passport (Hooper, 1995). When democracy was instated, substantial changes took place in family law and behavior: women's previous legal subordination to the husband was abolished, 
parental legal authority over children became shared between both parents, women were guaranteed equal footing to men in the administration and disposition of acquired assets. In 1981 divorce was legalized. The law was quite restrictive and legal separation and divorce were still relatively uncommon until the 1990s, but subsequent pressure to speed up the legal procedure led to the Spanish Divorce Reform of 2005 that permitted no-fault divorce.

It was between the initial Divorce Law of 1981 and its reform in 2005 that our respondents divorced (Figure 1). During this period, divorce was still less common and more stigmatized than today. However, divorce would neither have been thinkable nor feasible for most of our study population was it not for the educational expansion and associated increased gender awareness and labor opportunities for women. Indeed, during the 1980s and 1990s the male breadwinner model still dominated in a dual labor market that was too rigid and complex (Davia \& Hernanz, 2004). As a result, combining professional with family life was still difficult. This was especially so for women of lower socioeconomic status as they were (and many still are) the ones who were penalized when they left the labor market to devote to the care of children or the elderly. As economic factors could be a barrier to (or a cause for) divorce our sample was restricted to employed and higher educated individuals.

\section{A Brief Literature Review of Divorce Biographies}

For many interviewees in Vaughan's (1986) book on turning points in intimate relations the divorce process began with the unsatisfied partner creating a small territory that confirms an identity independent of the coupled identity. As time passes, the initiator reacts in additional ways that further divide the couple. Disillusioned, the initiator becomes increasingly preoccupied with the ways partner and relationship fail, focusing more and more on the flaws and differences rather than positive traits and similarities. 
Consistent with the respondents' social context at the time, children were most likely to live with their mother after divorce, who was expected to fully resume care responsibilities. The assignment of custody to the father was exceptional in Spain because fathers often didn't ask for it, were discouraged to so by lawyers, or because it could be considered a sign that the mother was lazy or incompetent (Catalán-Frías, 2011). A content analysis of 782 Spanish child custody cases between 1993 and 1999 showed that just $8.4 \%$ of the cases were granted to fathers, who more often required a ground of motivation than mothers to obtain custody ( $62 \%$ vs. $40 \%)$, frequently based on the criteria of exclusion of the mother (Arce et al., 2005). This is consistent with Municio's (2013) qualitative study on Estonia and Latvia, who found that mothers were permanent in their role as carers, while fathers were interchangeable.

Not only family law but also a new union and the possibility of new maternities or paternities can affect father-child and mother-child relationships after divorce differently (Coleman et al. 2000), although the literature does not agree on how. According to a British (Berrington et al., 2006) and French (Villeneuve-Gokalp, 2000) study, men tend to see children from their previous union less often when they start a new relationship, while women in the same situation reinforce the mother-child relationship and may encourage father-child contacts. According to Amato and Booth (1996) divorce weakened affection between fathers and children (mainly because few fathers obtain joint or sole custody), while low marital quality prior to divorce affected parent-child affection for both parents. Recent evidence for Germany has shown that although women after divorce seem to be the central figure in all types of families, stepmother families are the most egalitarian in terms of time and activities with the children, division of housework, quality of partnership and family climate (HeintzMartin et al., 2015). Lastly, Martin (1994) found that for non-resident fathers living near 
their children, paternal socio-economic variables (income, education level) become important for maintaining ties. This is another reason why for the present study no individuals faced with economic difficulties were selected.

Literature from Finland (Castrén, 2008; Ketokivi, 2008), France (Martin, 1994) and the US (Johnson, 1989) suggest that there are three important determining factors regarding the (re)definition of family configurations after divorce, each of which are also analysed here: the child custody status of the divorced parents, the centrality of children and the role of close friends. Moreover, Castrén (2008) advocates that to better understand post-divorce family configurations the composition and dynamics of postdivorce family and kin configurations should be studied in addition to the characteristics of the relationship and of the partners. This involves (expectations of) loyalty, solidarity and obligation. Her study of 34 (once) divorced women and men with children showed that loyalty may be transferred to the new conjugal tie or shared between the former and present in-laws. Moreover, as mothers often have (sole/more) custody over their children than fathers do, one US study of 50 parent-grandmother dyads showed that the paternal grandmothers have more trouble than maternal grandmothers in maintaining access to their grandchildren as they usually only obtain access by maintaining good contact with the ex-daughter-in-law. This situation becomes worse when their adult son remarries (Johnson, 1989). Finally, the role of close friends becomes evident in the research on significant others by Ketokivi (2008) who found that marital disruption activates relationships. When friends act in a family-like manner the significance of friendship may approach to that of the family configuration. Alternatively, when family and friends hold specialized roles, friendship may gain its significance precisely from non-relation to the family members. A similar fuzzy boundary between family, friends, 
home, love and sexuality was found in the British study by Roseneil and Budgeon (2004).

In each dimension gender is intertwined. As West and Zimmerman (1987) argued in their conceptual paper on "doing gender", gender is not something we are, but something we do. Gender is continually socially reconstructed in light of normative conceptions of men and women. People act with the awareness that they will be judged according to what is deemed appropriate feminine or masculine. However, in response to West and Zimmerman, Deutsch (2007) argued that the term "doing gender" undermines "the goal of dismantling gender inequity by unwillingly perpetuating the idea that the gender system of oppression is hopelessly impervious to real change and by ignoring the links between social interaction and structural change". Instead she asserts that what should be understood are the social processes that underlie resistance against conventional gender relations and how successful change in the power dynamics and inequities between men and women can be accomplished. For Deutsch the doing gender approach implies that if gender is constructed, then it can be deconstructed ("undoing gender"). Gendered institutions can be changed, and the social interactions that support them can be undone. Particularly marriage is a site for "doing" gender, given the potentially high level of gender differentiation in breadwinning, housework, parenting, and emotional expression (Walzer, 2008). In fact, despite a changing relationship between domestic practices and gendered subjectivities this has not yet led to a fundamental "democratization" of domesticity with significantly greater equality between men and women, as was demonstrated by an ethnographic study by Meah and Jackson (2012) on kitchen practices in South Yorkshire (UK). Furthermore, in Spain, data of the Time Use Survey 2002-03 reveal that on average men do 30\% of the domestic work that is performed by one of the members of the couple, only $17 \%$ of co- 
resident males do at least half of domestic tasks and co-responsibility is minimal in couples where women are not in paid work (González \& Jurado-Guerrero, 2009).

Conversely, divorce could be an opportunity for "undoing" gender for both sexes, although there is little evidence to support this. What's more, according to Walzer (2008) divorce may actually generate "redoing" gender in the sense that some people identify and modify expectations for male and female behavior in families. Walzer does not call this "undoing" because "there is still awareness of and accountability to gender". Rather, it is "redoing" because people remain cognizant of the possibility of gender assessment, but they describe changes in their own perceptions of the inappropriateness of their gender violations. They hold themselves to different standards on the other side of marriage. In Lithuania, although divorced fathers' role consists primarily of their financial responsibility, recent results have shown that divorced fathers defy gender normativity and undo the traditional fatherhood while they refute the widespread assumptions about men's secondary role as caregivers (Tereškinas \& Maslauskaitè, 2018). A recent study based on a sample of Swedish divorced fathers report the fathers' subjective aspirations to carry on family practices in gender-equal ways after divorce, but such aspirations are filtered through structural and cultural conditions in society (Andreasson \& Johansson, 2019).

\section{Research design}

Previous research on union dissolution in Spain based on divorce registry and survey data (AUTHOR(S) 2007; 2012; 2016) opened up new questions for quantitative research to investigate in detail its determining factors and consequences. The breaking up of a union cannot be reduced to a simple event since it involves a redefinition of emotional ties and family relationships, which becomes especially complex when there are children involved. Therefore, in light of the earlier discussed gendered paths in 
mothering and fathering and family reconstructions following a union breakdown, the aim of the present study is to ascertain whether gender differences are the norm or if there is room for "undoing gender". The best way to understand factors explaining family biographies and explore logics and gendered practices and beliefs about different dimensions of the divorce process, how mother- and fatherhood is redefined, and family configurations are reshaped after a union dissolution is taking a qualitative approach through in-depth interviews.

Specifically, the present study aims to answer the following questions: To what extent does motherhood and fatherhood after the union dissolution relate to motherhood and fatherhood before? Does the break-up bring about a redefinition of bonds in terms of nuclear and extended families?

\section{The sample: Derived from the pre-divorce trajectory}

The sample consisted of 13 men and 13 women who were unrelated and who met the following requirements:

- Having had at least one child in the relationship that broke up.

- The union had dissolved between 3 and 15 years before the interview.

- Born between 1948 and 1968 (aged 40-60 years at the time of the interview), making them a pioneering social group of young adults in democratic Spain as they saw divorce legalized (1981), observed the highest percentage of divorcees according to the 2001 census but had divorced before the 2005 Divorce Reform (see Figure 1).

- $\quad$ Lived in a metropolitan area of Spain (Barcelona, Madrid, Valencia, Seville).

- Was in paid employment at the time of the interview. 


\section{[FIGURE 1 ABOUT HERE]}

No conditions are imposed concerning the type of union. Since our intention was to focus on aspects related to relationships and not so much on material factors, interviewees had to be economically active and belong to a homogenous social group. The sample was obtained using the snowball method by deliberately starting with people from our own social network without economic problems, some of whom then recommended other people in a similar socioeconomic and family situation. All respondents have a high level of education (most with a university degree) and were (self-)employed in the cultural, administrative and business (i.e. tertiary) sectors.

To test the interview guidelines four prior pilot interviews (two men and two women) were conducted in 2007 and in spring 2008 the 26 interviews were carried out, taking between one and two hours each (see AUTHOR(S) 2009) ${ }^{1}$.

\section{A Guide for the Interview}

The qualitative research approach followed the strategy of the biographical

${ }^{1}$ The Autonomous University of Barcelona has been only subscribed to the European Code of Conduct for Research Integrity (ALLEA) since 2013. Prior to this, qualitative research proposals did not require to be approved by an ethical committee and adhere to a Code of Best Practices. Nevertheless, security measures had been taken by the Principal Investigator as the recordings and transcripts of the interviews were exclusively kept under her surveillance. Moreover, all interviewees were informed that participation was voluntary and data would be treated with confidentiality. Prior to the interview, the interviewer presented the study and obtained oral informed consent from the participants, who were also given the option to end the interview at any time. Their consent is also included in the recordings of the interview. The names are anonymized in the interview transcripts. 
demographic surveys that were designed in different countries since the early $1980 \mathrm{~s}$ (Bozon, 2006). While in retrospective demographic surveys information on education, labor careers, family and residential changes are included, in our case the main subject is family life. It was left to the respondents to select the most important and meaningful events surrounding the formation of a partnership and family, the birth of children, the process of union disruption, and the period after break-up. The semi-structured in-depth interviews thus followed the life history approach in order to understand the respondent's meaning on selected events in their biography and particularly those related to family ties and emotional bonds.

The stories which the male and female interviewees told about their families were guided by five questions related to the union dissolution process and the (re)definition of family configurations. When needed, probing questions were used as a connecting thread to obtain more detailed answers from the general questions and to ensure a common thematic body throughout each interview:

(1) Tell me about your own family.

(2) Tell me, how did you experience the union break-up process?

(3) How have things gone after breaking-up?

(4) How do you feel about your present situation?

(5) Do you think men and women follow different paths after they have broken-up?

The interviewer intervened as little as possible, suggested some topics and built graphic material on the interviewee's genealogy and life course. The same interviewer (AUTHOR) conducted all 26 interviews.

The conversation was initiated by saying to the respondent "Tell me about your own family". The answer was nearly always: which family? My family of origin? The one I have created? The interviewer replied with "that is precisely what we are looking 
for, to know how people define their own family". At this moment, the respondent realized that there is no standard predetermined answer and started talking about his or her family. The interviewer listened while drawing in a fieldwork notebook the main people who configure the more or less complex family configuration (Figures 2 and 3 show simplified versions) and noted down the sex, the link with the interviewee and the way in which the emotional bonds or family ties were named.

[FIGURE 2 ABOUT HERE]

[FIGURE 3 ABOUT HERE]

\section{Analyzing the narrated biographies of divorce and family configurations}

The narratives of the respondents unveil the extent in which divorce was a turning point in their lives. They also provided important information on the changing family configurations and meaning of family and emotional ties, offering us clues to the nature of the emotional relationship at the time of the interview between the person and people he/she feels closest to, including biological or in-law family (children, (ex-)partner, parents, siblings, ...) and others (friends, classmates, colleagues, ...); and highlight factors that explain/relate to the family biography, in particular the process of union dissolution and the period afterwards. Finally, the interviews also endow key elements about the transformation of gender identities, gendered practices and beliefs among which those related to mothering and fathering are crucial.

Rather than performing a biographical analysis, we opted for a thematic analysis, focusing on just one part of the participants' biography, namely family life. This allowed us to bring to light the most common themes in the narratives related to the union breakup and its (family) consequences, analyze and interpret them (see also Blanchet \& Gotman, 1992; Staller, 2015). This was aided by the qualitative data analysis software ATLAS/ti which was also used for the coding procedure (see Table 
1). Pseudonyms are used throughout and direct quotations from Catalan and Spanish only appear in their English translation.

\section{[TABLE 1 ABOUT HERE]}

As can be observed from Table 1, from our thematic analysis of the findings three key themes — or units of meaning - were identified. To operationalize these themes we defined 10 dimensions or categories, each of which represented by one or more indicators ( 27 in total). These indicators were derived from the coding of the transcripts that were subjected to an inductive content analysis. Specifically, the following steps were undertaken by two of the researchers (see also Bécue-Bertaut, 2010; Braun \& Clarke, 2006; Ruiz Olabuenaga \& Ispizua, 1989):

(1) The interviews were recorded and verbatim transcribed, read and reread to familiarize ourselves with the data.

(2) Codes or initial indicators were generated. Several of the interviews were codified by both researchers to confirm that the definite codes were accurate and precise.

(3) The codes were organized in categories or dimensions from which the themes were extracted.

(4) We checked if the topics worked in the different fragments of the extracted biographies and redefined the associated codes when necessary.

(5) Analysis involves a constant moving back and forward between the entire data set. This method of constant comparison was used to identify emergent themes within and across interviews.

\section{Results}

The respondents' post-divorce biographies are shown in Table 2 and illustrate several 
dimensions of the so-called second demographic transition (SDT) (Lesthaeghe, 1995; Van de Kaa, 1987). Although they socialized during the Franco period and most married shortly after and divorced in the 1990s they could be considered Spanish pioneers of the SDT because they epitomized the transition from the traditional to the modern model of marriage where love develops gradually with pre-marital sex as a founding act of the relationship rather than marriage (Kaufmann, 1993). Moreover, as typical of the SDT, marriage is not necessarily meant for life or the need to remarry essential for the children. Indeed, just five out of the 26 had remarried at the time of the interview, while others cohabited, Lived Apart Together, were dating, had an unstable or no relationship at all. Six respondents shared the custody of their children with their ex-partner. In our attempt to answer the two research questions, results derived from two of the three interrelated themes extracted from the narratives are addressed in detail in this section: "Reconstruction motherhood/fatherhood after divorce" and "Redefinition of my family after divorce". The "Process of divorce", the first identified theme, is briefly touched up below.

\section{[TABLE 2 ABOUT HERE]}

Like Walzer and Oles (2003) we found that gender mediated how people talked about the process of uncoupling as well as their motives for divorce. For women, physical separation often means definitively breaking with emotional bonds. While they generally want no harm for their children's father, he is a person with whom they have nothing, yet for most men ties seem never to be broken forever. It is a mixture of a sense of responsibility, of protection, of the right to administer a women's life, of property. It is sometimes difficult for them to renounce to their former role, even when they have started another relationship. However, this feeling of possessiveness can also 
be formulated by women: "I divorce from you, but you are mine" (Gradiva, born in 1955, 1 daughter at the time of divorce).

Children's central role in the divorced mothers and fathers lives also stands out clearly. Nearly everything in life after divorce is influenced by children's needs and experiences, particularly during their childhood and adolescence. For example, establishing a new union can be put aside or even rejected because children are given absolute priority (Table 1, indicator 8). Even though this does not mean renouncing to establish new stable relationships, the idea of forming a new common household with a partner is rejected. As men do not normally live with their children, this is an even more common option for them.

\section{Reconstruction on motherhood/fatherhood after divorce}

Perceptions of fatherhood and motherhood and their specific experience of it, is known in the sociological literature as mothering and fathering (Silverstein, 1996). From our respondents' narratives, it seemed that fatherhood/fathering and motherhood/mothering after divorce reproduced the roles each of them had before divorcing, suggesting that parent's post-divorce responsibilities on child care is linked to pre-divorce ones. In the interviews, we explored the fuzzy boundaries and common territories in marriage and divorce stemming from stories which our respondents told on the (re)construction of mothering and fathering after divorce. What we expected to observe following the traditional model of gender roles was that the children's role in women's lives was more central than in men's; children would normally stay with their mother after divorce while the father left the family household; mothering was permanent and fathering, intermittent; for a father-man, taking care of children and a new union was totally compatible but difficult for mothers to do both; and that the decision for fathers to have children again was relatively easy but unfeasible for women. 
However, results showed that for all men and women their children played a central role and had an immense value. Yet, the way in which this motherhood or fatherhood took place was gender constructed. While mothering is considered an unavoidable duty, fathering is seen as a right rather than an obligation and exercising it can be problematic because men can be confronted with many restrictions. 12 mothers and 12 fathers talked about their presence but in different ways (Table 1 indicator 12): Mothers were tired of always having to take care of children and were unsatisfied due to the small amount of money and time fathers devoted to childcare. Fathers, however, moved between two opposite poles: on the one hand, there was their satisfactory view of fatherhood and of mother-father cooperation in fathering and mothering which borders idealism, but on the other some lacked possibilities of fathering (even though they obtained the formal legal right to do so). Although we have observed clear examples of the traditional model, the cases of Sol and Patrick were exceptions that allow us to talk about counter models in men and women. While no women-mother left the children with their father at the moment of breaking up, Sol, who was the main carer of her son until he was 12 , decided to abdicate this role to develop herself professionally. To do so, she appealed to the father. It was not an easy process, as she had to be assertive and strategic in her plea:

It all occurred at the same time, separating and losing my job (...). My son continued to live with me until he was 12 and then I realized I could not carry on: I was working a lot, I was very nervous, I was getting home very late, my son had bad results in his exams, so I called his father. I said: "Kramer, this is Kramer [citing Robert Benton's 1979 film Kramer vs. Kramer], didn't you want him?, he is all yours!" (...) we will tell him "we have decided ... together, you do not have anything to do with it, you are not bad, I am not bad, that for the sake of your future you will go and live with your father and then, maybe, you will come back and live with your mother again”. (...). And then I thought of my friends, because women, if you are a mother and you tell other women that you are not going to live 
with your son, my God, they all look at you as if you had turned really mad (...) it is much more politically incorrect that a woman decides to live without her child than getting separated. It's like if you were abandoning your child, it's a very strong feeling, yeah! (Sol, born in 1961, 1 son at the time of divorce).

It is also an example of how women may experience the practice and notion of non-residence parent differently from men (see also Kielty (2005)) and how noncustodial women exist outside the boundaries of normalised discourse (Eicher-Catt, 2004). More than showing the difficulties Sol found in swimming against the tide and the strategies she followed to reach her goal, this is a relevant testimony because it not only expresses the guilt many of the other mothers that were interviewed also felt, but also her sense of freedom when her son lives with his father.

However, not all fathers leave home as was the case of Patrick who was the main carer of three daughters before the break-up. Like in Moore (2012), Patrick's narrative is an example of how gender roles practiced during the marriage influenced the post-break-up family practices. Yet, in line of Walzer (2008) this would still be an example of redoing rather than undoing gender as the subject thinks that the mother would have done the role better:

When we started thinking about getting separated, I had always been in charge of the girls (...) I think a mother is more important than a father for daughters (...) because of affinity, they understand each other better (...) but [her] work was always in the middle, and then on top of this, it happened that she fell in love (...). Then, well, for (...) a couple of years, the girls were mainly with me and spent the weekends with Mar. It was very difficult, not particularly for me, because I gained this independence and I managed to do things more or less, but for the girls, it was very difficult for them (...) to go without their mother, I felt that they thought she was guilty of what was happening and Fausto (her new husband) too. (Patrick, born in 1960, 3 daughters at the time of divorce). 
Patrick took care of his three daughters until his wife, two years later, was granted shared custody. He does not repent it. In this sense, findings are similar to those found in other studies we mentioned earlier, i.e. relationships with children are particularly difficult for the parent who leaves home. It is nevertheless more difficult for women to transgress the traditional model of gender roles. While it is accepted that men should be incorporated to childcare it is not so easy for women to abandon their caregiving role. It is understood as a kind of betrayal, perhaps similar to that when women remained in paid work after marriage that carries a sense of guilt which requires determination to overcome. Finally, there was also a sense of betrayal among divorced men who felt excluded and depressed when the possibilities of being near their children were being restricted.

\section{Redefinition of my family after divorce: a broader family?}

Similar to findings by Ketokivi (2008) and Lelièvre and Vivier (2006), family forms diversified (including parental figures) and emotional bond networks became more complex after divorce (like in Sclater, 1997). As mentioned earlier, the interviewees were surprised when asked to talk about their own family as there is no unique expected answer. Their reactions (see indicators 15-17 of Table 1) led us to the conclusion that family does not fit into a unique pre-defined permanent identity. It is continuously being re-defined, and is perceived through events giving sense to each person's biography. Divorce in this sense, is a crucial event. Some interviewees told us that if they had been asked the same question before separating, they would have undoubtedly answered that “my family is my small family, my partner and my children".

After divorce, respondents define their own family by appealing to blood-kin or in-laws (my family, my children's family), co-residence, or not (who lives in the household) and/or affinity and love (elected family) (see Figures 2 and 3 and indicators 
18-27 of Table 1). Answers on blood-related family can refer to two generations ("myself and my children"), three ("also my father/mother") or four ("as well as my grandparents"); and may also include other kin (siblings, cousins, nephews, and nieces). The case of Mimo is illustrative: despite his complex family trajectory (two divorces and three children from two different women), in his perception of family he only considers his parents and three children, but excludes his ex-partners, children-in-law and grandchildren (Figure 2). The exclusion of his grandchildren suggests that blood is not a guarantee to belong to one's family (indicators 15 and 17, Table 1). Some respondents even said that their children are much more than a family member. For Pedro "my daughter is even more than a daughter, she is the only one in the universe". Reasons why other blood-related kin are considered family (indicators 18-19, 24-26, Table 1) go from gratitude to responsibility or support (see also Castrén, 2008; Johnson, 1989). Quotes from our respondents include "taking care of a mother to thank her for having brought me to life", "you can always count on them", "parents and children will never fail you, partners are another thing". Siblings and cousins are often also considered as family because of daily life relationships, co-residence, complicity or mutual support. Siblings are interesting because they are blood-kin, they are there, but sometimes are emotionally further away than close friends, although bonds may be revived when there is a family crisis as our interviewees told us. Uncles, aunts and grandparents may also have had a particular impact in the respondents' lives.

Divorce does not necessarily exclude prior relationships with in-laws in one's own family. While divorce splits up one's life it does not affect those relatives who are linked through the couple's child(ren) in the same way as relationships acquired through marriage often continue existing. Mixing in-laws and blood-kinship shows that interviewees have defined their own families through their children's one, a finding that 
was also observed by Castrén (2008). In our sample, only a few incorporated their expartner but they did include their ex-mother in-law (e.g. Eva and Júlia) or their expartner's nephews and nieces, i.e. their children's grandparents and cousins.

However, gender differences remain. More men than women include the expartner in the family: "My children's mother will always be different from all other woman, separating hasn't changed anything in this sense" (Andreu) or maybe because responsibility goes beyond divorce. For example, Patrick said: "If something happened to her or her new husband, I would take charge of the daughters we have in common and her new daughter".

"Chosen family" has also its space (indicators 20, 24-25, Table 1). In a broader sense, close friends with whom there is a tighter relationship than with siblings can also be considered family members. Especially women integrate friends who help to take care of their children into their family. One example of this complex family configuration is the case of Angela as shown in Figure 3 and also illustrates that family, sex and affection can be located outside the household walls. Similar results have also been found in France (Martin, 1994) and Finland (Ketokivi, 2008).

Others talked about their broader families that included blood-kin, in-laws and "chosen family" in terms of tribes. This seemed to be related to international migratory trajectories, reconstituted families after divorce and multiple divorces of the respondents.

Family and co-residence are not equivalent concepts, especially for the divorced whose own family is not exclusively located in the same household. Therefore, the way in which family demography tends to study family relationships -i.e. households- loses precision in a post-divorce scenario. Indeed, our results generally support Le Bras' (2003) idea that family does not allow itself to be studied. Living alone does not mean 
not having a family, a stable relationship with a partner, or strong emotional bonds. A one-person household for some days a week can become a one-parent household from time to time, or certain weekends, when, for example, children come to live with their father or mother (the case of Mimo, Figure 2). Moreover, co-residence does not automatically give the right to belong to the other person's family, not even when you live as a couple. An example of this would be Alejandra who perceives her parents and her two sons, one from the previous and one from the present partner as her family. However, although her present partner is the father of her second child he is not included, "family is another thing". On the contrary, Julia includes her current partner, who is the father of their two youngest children, in her family configuration.

\section{Discussion}

The targeted age and social group of the respondents was very specific (high educated (self) employed professionals) because our intention was to focus on certain aspects related to relationships rather than material factors. They had become adults and began their love life during a time when Spain became democratic, opened itself to the world and underwent significant social and family changes. Drawing on narrative interviews, we studied two issues: the redefinition of "parenthood" after divorce and what is considered as "my family". While results from our investigation cannot be generalized to the total population, several important points must be highlighted:

One of the main contributions of this study is the discussion of certain concepts that are often considered as static despite them being in constant change. Our results also showed that mothering and fathering after divorce was intense among all respondents and related to the mothering/fathering before the break-up, as indicated by the centrality of the children from their first union. Yet while practically all had entered new, more or less stable relationships, only two, both women, had had children from a 
second union. This is not unexpected though, because half of the women ended their first marriage after the age of 40, i.e. an age when few women decide or are able to have children. We are not able to say why there were no new biological paternities (i.e. an outcome somewhat contrary to the expected gender model). One male respondent did state a desire to have children and another to adopt one.

Our results confirm that after divorce, families with children become broader and more complex, as has been shown earlier by Le Bras (2003). We also provided evidence about the (fuzzy) boundaries between family, home, love and sexuality as Roseneil and Budgeon (2004) did. The dimension of the respondents' family was extended to relatives, loyal friends and in-laws to satisfy the role of brothers or sisters, while new stable unions did not necessarily translate into co-residential experiences. Both in the classic work by (Levi-Strauss, 1956) and in other studies on family life (e.g. Brullet, 1997; Gittens, 1993), the plurality of family forms are an important common line to ethnographic studies on the family. Our results also showed that, in this sample of pioneer divorcees, family forms after divorce overcame the boundaries of biparental nuclear families as changes in co-residence did not necessarily weaken family links among the respondents. Perceptions of families were deeply redefined after divorce. Nevertheless, family transformations after divorce were shaped differently by women and men as family roles were gendered depending on identities and practices, which configured the social norms after divorce. This is particularly relevant when the focus is on mothering and fathering whose practices during the union shape the way in which they are going to be constructed after divorce.

Gender transcends all divorce-related issues as there are both clear differences and similarities in the biographies of divorce for men and women. For women, physical separation often means definitively breaking with emotional bonds while for most of 
men ties seem never to be broken forever. Yet for both men and women, the children's central role in their lives stands out clearly. Divorce is also an important source of gender transformation.

In Spain, families still constitute the most important net of solidarity, safety, and welfare. Individuals rely on their direct and extended families as a source of continuous support. While in Nordic European countries, like Finland, Sweden or Norway family change was defined by the development of generous family and gender policies in the so-called 'context of individualization', in Southern European countries such as Spain, the transition process from a traditional family to a more egalitarian one is ambivalent. According to Moreno Mínguez (2010), to understand such social and family change trends it is necessary to integrate the individual aspirations with the structural determinations. Although family models have become more flexible and less solid, the weight of tradition and familist values are still important in the strategies adopted by Spanish people (ibid.).

Statistics show that, like in other Mediterranean countries, the frequency with which parents contact daily adult children is in Spain twice the frequency observed in Denmark and Sweden. The same can be said about the contact with parents, which stands out in the Mediterranean countries (Kohli et al., 2005). Furthermore, in Western Europe, important differences have been found between what these authors have called "Strong family countries" in Southern Europe, with high rates of co-residence and frequency of contact among adult family generations, and the "weak family countries" in the North. Moreover, the extended family is also very important in Southern Europe as it represents an important substitute for formal childcare (Moreno Mínguez, 2010).

When asked: "Which/who is your family?", the majority of the men and women in the sample referred to their family of origin, their nuclear or "created" family, other 
kin bonds (extended family) or even their adopted family that includes friends (in the case of women) (indicators 15-17, Table 1). This has to do with the widely shared idea that one's own family is much more than the space composed of parents, brothers, and sisters representing the heterosexual Christian traditional nuclear family. The interviewees are referring to these kinds of family forms when they describe the family that emerges after their union's breakdown and the end of the family nucleus. These new and therefore alternative family forms have more to do with those close friends and relatives - coming from different relationships - with whom one knows one can count on for support during difficult times or, for instance, when help is required to take care of the children. Support is also often reciprocated when asked. This connects to the concept of the chosen family and with the voluntary kin relationships. As Jencson (2016) states , such family forms have the potential to move society toward increased acceptance of new familial relationships behaviors and forms. In their qualitative study on voluntary kin relationships in the USA Braithwaite et al. (2010) found that members of such relationships experience them challenging, requiring discursive work to render them sensical and legitimate to others because they are not based on the traditional criteria of association by blood or law. The authors also find that among the different types of voluntary kin relationships, only the extended family was constructed without the justification of deficiency in the family of blood or law.

Based on our post-divorce analysis on motherhood and fatherhood reconstruction, there are three important contributions we can make to the debate on the impact of divorce in redefining fathering, mothering and family arrangements from a gender perspective. First, we observe that institutionally, divorce does not contradict marriage. This goes in line with Moore's (2012) evidence suggesting that the renegotiation of family practices after divorce is heavily influenced by the gendered 
roles during marriage. Second, our results also suggest that divorce helps to reveal the real nature of marriage and vice versa in terms of gender relations. A third contribution is that while gender is a crucial element to understand the dynamic of couples' behavior, divorce is also an important source of gender transformation.

Our finding on "transgressing" the expected parental role model suggests that change is (slowly) on its way, at least among couples with similar age, residence and socioeconomic characteristics as those in our sample. Most of the mothers and fathers interviewed can be situated between the traditional and the counter/new family model. There are fathers who have built a more balanced childcare model before breaking up and mothers who decide to keep a certain physical and emotional distance with their children's care when they start to be a little older so that they do not have to give their own projects up.

Despite the persistent gender asymmetry in Spanish labor market and domestic life, gender identities are often negotiated, providing opportunities for doing, undoing or redoing gender. If we would strictly follow Walzer's (2008) reasoning, none of the interviewed divorcees were "undoing" gender because of their awareness of and accountability to gender. However, if we would not consider perceptions but actual individual behavior than there were two clear examples in our study of undoing gender despite there being a sense of guilt: Sol, who allowed the father to have custody over the children and Patrick who considered that his ex-wife would do a better job at taking care of the children. Our results not only showed that what would be traditionally called "female behavior" can be perfectly personified by a man-father but also that typical "male behavior" can be carried out by a woman-mother. Nevertheless, undoing gender is the exception, not the rule, which is generally doing gender before the breakup and redoing afterwards. 
Lastly, moving from post-divorce parenthood to the redefinition of "my family" post-divorce, our findings suggest that all those transformations may be seen as one important source of the general process of the "modernization of the Spanish family", viewed through the diversity of fathering and mothering styles and their process of doing and undoing gender. On this note, future research on family (re)configurations after divorce in Spain could focus on the narratives of children affected by divorce to see whether the break-up of the nuclear family provided them also with an opportunity to reflect on family ties in a new way, as Berman (2015) recently observed for Swedish children.

\section{Disclosure statement}

No potential conflict of interest was reported by the authors

\section{Funding}

For anonymity purposes, this will be stated after the manuscript has been accepted.

\section{References}

Author(s). 2007.

Author(s). 2009.

Author(s). 2011.

Author(s). 2012.

Author(s). 2016.

Amato, P. R., \& Booth, A. (1996). A prospective study of divorce and parent-child relationship. Journal of Marriage and the Family, 58(2), 356-365. doi: $10.2307 / 353501$

Andreasson, J., \& Johansson, T. (2019). Becoming a half-time parent: Fatherhood after divorce. Journal of Family Studies, 25(1), 2-17. doi:10.1080/13229400.2016.1195277

Arce, R., Fariña, F., \& Seijdo, D. (2005). Razonamientos judiciales en procesos de separación: análisis cognitivo y de contenido de las motivaciones. Psicothema, 17(1), 57-63.

Bécue-Bertaut, M. (2010). Minería de textos: Aplicación a preguntas abiertas en encuestas [Text mining: Application to open questions in surveys] (Vol. 38 of Cuadernos de Estadística). Madrid: La Muralla. 
Berman, R. (2015). (Re) doing parent-child relationships in dual residence arrangements: Swedish children's narratives about changing relations postseparation. Zeitschrift für Familienforschung-Journal of Family Research, 27(Special Issue), 123-140.

Berrington, A. M., Cobos, M. I., Ingham, R., \& Stevenson, J. C. (2006). Non-resident fatherhood in Britain: Factors affecting contact and the payment of maintenance. Paper presented at the European Association for Population Studies, Liverpool.

Blanchet, A., \& Gotman, A. (1992). L'Enquête et ses méthodes: L'entretien [The survey and its methods: The interview] (Vol. 128). Paris: Nathan Université.

Bozon, M. (2006). L'apport des méthodes qualitatives en démographie [The contribution of qualitative methods in demography]. In G. Caselli, J. Vallin, \& G. Wunsch (Eds.), Démographie, analyse et synthèse (Vol. 8, pp. 433-457). Paris: INED.

Braithwaite, D. O., Bach, B. W., Baxter, L. A., DiVerniero, R., Hammonds, J. R., Hosek, A. M., . . Wolf, B. M. (2010). Constructing family: A typology of voluntary kin. Journal of Social and Personal Relationships, 27(3), 388-407. doi:10.1177/0265407510361615

Braun, V., \& Clarke, V. (2006). Using thematic analysis in psychology. Qualitative research in psychology, 3(2), 77-101. doi:10.1191/1478088706qp063oa

Brullet, C. (1997). Pràctiques de criança i identitats parentals [Parenting practices and parental identities]. Papers de Sociologia, 51, 149-170.

Castrén, A.-M. (2008). Post-divorce family configuration. In E. D. Widmer \& R. Jallinoja (Eds.), Beyond the nuclear family: Families in a configurational perspective (pp. 233-254). Bern: Peter Lang.

Catalán-Frías, M. J. (2011). La custodia compartida [Joint physical custody]. Revista Derecho y Criminología. Anales 2011, 1, 57-82.

Davia, M. A., \& Hernanz, V. (2004). Temporary employment and segmentation in the Spanish labour market: An empirical analysis through the study of wage differentials. Spanish Economic Review, 6(4), 291-318. doi:10.1007/s10108-0040086-2

Deutsch, F. M. (2007). Undoing gender. Gender \& Society, 21(1), 106-127. doi: $10.1177 / 0891243206293577$

Eicher-Catt, D. (2004). Noncustodial mothering: A cultural paradox of competent performance-performative competence. Journal of Contemporary Ethnography, 33(1), 72-108. doi:10.1177/0891241603259811

Gittens, D. (1993). The family in question. London: The MacMillan Press Ltd.

González, M. J., \& Jurado-Guerrero, T. (2009). ¿Cuándo se implican los hombres en las tareas domésticas?: Un análisis de la Encuesta del Tiempo [When men are involved in household chores?: An analysis of the Time Survey]. Panorama Social, 10, 6581.

Heintz-Martin, V., Entleitner-Phleps, C., \& Langmeyer, A. N. (2015). "Doing (step) family": Family life of (step) families in Germany. Zeitschrift für

Familienforschung-Journal of Family Research, 27(Special Issue), 65-82.

Hooper, J. (1995). The New Spaniards. London: Penguin Books

Iglesias de Ussel, J. (1998). La familia y el cambio político en España [Family and political change in Spain]. Madrid: Tecnos.

Jencson, L. J. (2016). Chosen families, TV and tradition: Queering relations in the BBC's Sherlock. In L. R. Porter (Ed.), Who is Sherlock?: Essays on Identity in Modern Holmes Adaptations (pp. 140-155). Jefferson, North Carolina: McFarland \& Company, Inc., Publishers. 
Johnson, C. L. (1989). In-Law Relationships in the American Kinship System: The Impact of Divorce and Remarriage. American Ethnologist, 16(1), 87-99. doi:10.1525/ae.1989.16.1.02a00060

Kaufmann, J.-C. (1993). Sociologie du couple [Sociology of the couple].

Ketokivi, K. (2008). Biographical disruption, the wonded self, and the reconfiguration of significant others. In E. D. Widmer \& R. Jallinoja (Eds.), Beyond the nuclear family: Families in a configurational perspective (pp. 55-278). Bern: Peter Lang.

Kielty, S. (2005). Mothers are non-resident parents too: A consideration of mother's perspectives on nonresidential parenthood. Journal of Social Welfare and Family Law, 27(1), 1-16. doi:10.1080/09649060500085487

Kohli, M., Künemund, H., \& Lüdicke, J. (2005). Family structure, proximity and contact. In A. Börsch-Supan, H. J. Brugiavini, J. Mackenbach, J. Siegrist, \& G. Weber (Eds.), Health, Ageing and Retirement in Europe. First Results from the Survey of Health, Ageing and Retirement in Europe (pp. 164-170). Mannheim: Mannheim Research Institute für the Economics of Ageing.

Le Bras, H. (2003). L'illusion familiale [The family illusion]. In M. Iacub \& P. Maniglier (Eds.), Famille en scènes bousculée, réinventée, toujours inattendue. Paris: Autrement.

Lelièvre, É., \& Vivier, G. (2006). Les figures parentales dans l'enquête 'Biographies et entourage' [Parental figures in the survey 'Biographies and environment']. In AIDELF (Association International des Démographes de Langue Française) (Ed.), Enfants d'aujourd'hui diversité des contextes, pluralité des parcours. Paris: Presse Universitaires de France.

Lesthaeghe, R. (1995). The second demographic transition in Western countries: An interpretation. In K. O. Mason \& A.-M. Jensen (Eds.), Gender and family change in industrialized countries (pp. 17-62). Oxford: Clarendon Press.

Levi-Strauss, C. (Ed.) (1956). Family. New York: Oxford University Press.

Martin, C. (1994). Diversité des trajectoires post-désunion. Entre le risque de solitude, la défense de son autonomie et la recomposition familiale [Diversity of postseparation trajectories. Between the risk of loneliness, the defense of its independence and family recomposition]. Population, 6, 1557-1583.

Meah, A., \& Jackson, P. (2012). Crowded kitchens: the 'democratisation' of domesticity? Gender, Place \& Culture, 19(1), 1-19. doi:10.1080/0966369X.2012.701202

Moore, E. (2012). Renegotiating roles postdivorce: A decisive break from tradition? Journal of Divorce \& Remarriage, 53(5), 402-419. doi:10.1080/10502556.2012.682892

Moran, G. M. (1995). The Spanish system of church and state. Brigham Young University Law Review, 535-553.

Moreno Mínguez, A. (2010). Family and gender roles in Spain from a comparative perspective. European Societies, 12(1), 85-111. doi:10.1080/14616690902890321

Municio, I. (2013). Matriarchal families and interchangeable fathers: How discourses on parenting allocate positions to women and men in post-divorce families. Huddinge, Sweden: Södertörns högskola. Retrieved from https://bibl.sh.se/skriftserier/hogskolans skriftserier/Matriarchal families and inte rchangeable fathers/diva2 656897.aspx

Roseneil, S., \& Budgeon, S. (2004). Cultures of intimacy and care beyond 'the family': Personal life and social change in the early 21 st century. Current Sociology, 52, 135-159. doi:10.1177/0011392104041798 
Ruiz Olabuenaga, J. I., \& Ispizua, M. A. (1989). La descodificacion de la vida cotidiana: metodos de investigacion cualitativa [Daily life decodification: Qualitative research methods]. Bilbao: Universidad de Deusto.

Sclater, S. D. (1997). Narratives of divorce. The Journal of Social Welfare \& Family Law, 19(4), 423-441. doi:10.1080/09649069708410209

Silverstein, L. B. (1996). Fathering is a feminist issue. Psychology of Women Quarterly, 20(1), 3-37. doi:10.1111/j.1471-6402.1996.tb00663.x

Staller, K. M. (2015). Qualitative analysis: The art of building bridging relationships. London: Sage Publications.

Tereškinas, A., \& Maslauskaitè, A. (2018). Undoing fatherhood: Postdivorce fathering practices in Lithuania. NORMA, 1-17. doi:10.1080/18902138.2018.1494401

Van de Kaa, D. J. (1987). Europe's Second Demographic Transition. Population Bulletin, 42 (1 (Washington D.C.: Population Reference Bureau)).

Vaughan, D. (1986). Uncoupling: Turning Points in Intimate Relationships. New York: Oxford University Press.

Villeneuve-Gokalp, C. (2000). The double families of children of separated parents. Population: An English Selection, 12, 111-138.

Walzer, S. (2008). Redoing gender through divorce. Journal of Social and Personal Relationships, 25(1), 5-21. doi:10.1177/0265407507086803

Walzer, S., \& Oles, T. P. (2003). Accounting for divorce: Gender and uncoupling narratives. Qualitative Sociology, 26(3), 331-349. doi:10.1023/A:1024066209821

West, C., \& Zimmerman, D. H. (1987). Doing gender. Gender \& Society, 1(2), 125 151. doi:10.1177/0891243287001002002 
Table 1. Themes, dimensions and coded indicators of divorce from 26 narratives. Respondents and citations per item

\begin{tabular}{|c|c|c|c|c|c|c|c|}
\hline \multirow[b]{3}{*}{ Theme } & \multirow[b]{3}{*}{ Dimension } & \multirow[b]{3}{*}{ Indicator* } & \multirow[b]{3}{*}{ Code } & \multicolumn{4}{|c|}{ RESPONDENTS AND CITATIONS PER ITEM } \\
\hline & & & & \multicolumn{2}{|c|}{ WOMEN (N=13) } & \multicolumn{2}{|c|}{$\operatorname{MEN}(\mathbf{N}=13)$} \\
\hline & & & & \# respon- & \# citations & \# respon- & \# citations \\
\hline \multirow{7}{*}{ Process of divorce } & Determinant factors/triggers & Trigger of rupture & 1 & 12 & 31 & 13 & 51 \\
\hline & & Profound reasons & 2 & 13 & 67 & 13 & 74 \\
\hline & & Failure/opportunity & 3 & 13 & 77 & 13 & 112 \\
\hline & & Frustration/dissatisfaction & 4 & 10 & 12 & 10 & 11 \\
\hline & Meanings & Role of children in the divorce process & 5 & 4 & 21 & 5 & 44 \\
\hline & & Feelings about ex-partner & 6 & 4 & 9 & 4 & 17 \\
\hline & & Gender differences & 7 & 12 & 28 & 12 & 28 \\
\hline \multirow{7}{*}{$\begin{array}{l}\text { Reconstruction of } \\
\text { Motherhood/fatherh } \\
\text { ood post-divorce }\end{array}$} & Bond (at the moment of the interview) & Centrality of children & 8 & 13 & 61 & 13 & 67 \\
\hline & & Father/mother breaks with children & 9 & 1 & 4 & 7 & 32 \\
\hline & Union break-down & Mother/father doesn't break with children & 10 & 13 & 72 & 2 & 4 \\
\hline & Motherino/fatherino & Father/mother not present & 11 & 3 & 3 & 13 & 35 \\
\hline & Diomerng/latnerng & Mother/father present & 12 & 12 & 55 & 12 & 72 \\
\hline & Compatibility previous children with new union & Advantages and constraints & 13 & 13 & 40 & 10 & 45 \\
\hline & New maternity/paternity & New/desired/no desired parenthood & 14 & 13 & 14 & 5 & 8 \\
\hline \multirow{13}{*}{$\begin{array}{l}\text { Redefinition my } \\
\text { family post-divorce }\end{array}$} & & My family & 15 & 13 & 70 & 13 & 51 \\
\hline & Linguistic use & My family of origin & 16 & 10 & 32 & 12 & 45 \\
\hline & & My nuclear family (created) & 17 & 11 & 33 & 11 & 32 \\
\hline & & My family, ascendents \& descendents & 18 & 5 & 10 & 5 & 11 \\
\hline & Mornhologicl use & My family, other kin bonds (extended family) & 19 & 10 & 30 & 8 & 13 \\
\hline & Morpnologicar use & My adoptive family, including friends & 20 & 9 & 20 & 4 & 7 \\
\hline & & My family, a tribe & 21 & 5 & 8 & 7 & 9 \\
\hline & & My family, instinct & 22 & 5 & 20 & 9 & 26 \\
\hline & & My family roots & 23 & 6 & 15 & 3 & 7 \\
\hline & Inclusion criteria & My family, complicity & 24 & 12 & 60 & 11 & 30 \\
\hline & (III) & My family, cooperation & 25 & 10 & 29 & 9 & 18 \\
\hline & & My family, duty & 26 & 10 & 61 & 8 & 45 \\
\hline & & My daily family & 27 & 8 & 28 & 6 & 9 \\
\hline
\end{tabular}

Note: *Refers to whether the respondent talked about the indicator, not necessarily if it applied to them personally. For instance, several talked about the issue of new maternities/paternities, but were ambiguous when it came to their own wish. 
Table 2. Biographies of unions, union crisis and post-break-up family formation of 26 men and women living in metropolitan areas in Spain. Spring 2008.

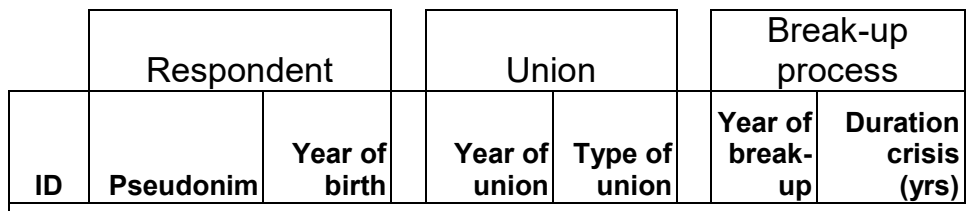

\begin{tabular}{|r|r|r|r|r|r|r|r|}
\hline \multicolumn{1}{|c|}{ Women } \\
\hline 1M & Àngela & 1951 & 1975 & married & 2005 & 18 \\
\hline $2 \mathrm{M}$ & Gradiva & 1955 & 1975 & married & 1993 & 15 \\
\hline & & & & & & & \\
\hline
\end{tabular}

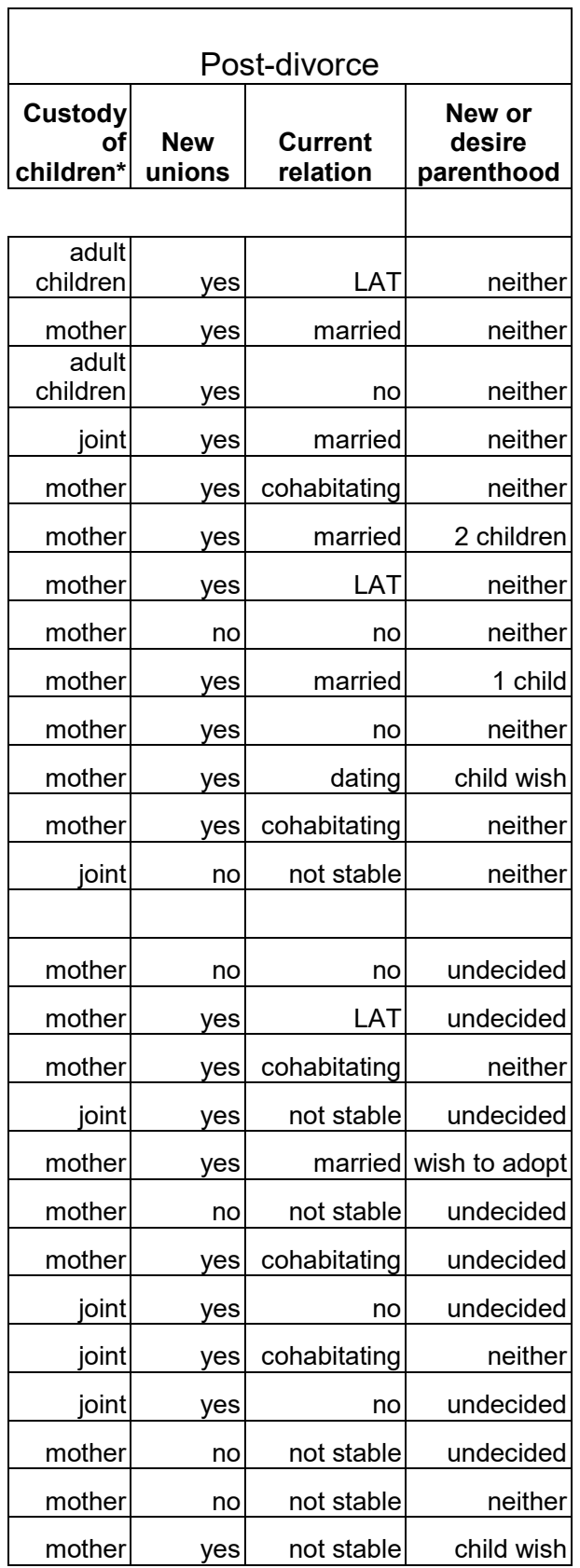

Note: *self declared 
Figure 1. Lexis diagram of the respondents in the context of the 1981 Divorce Law, the 2005 Divorce Law Reform and the time of the survey.

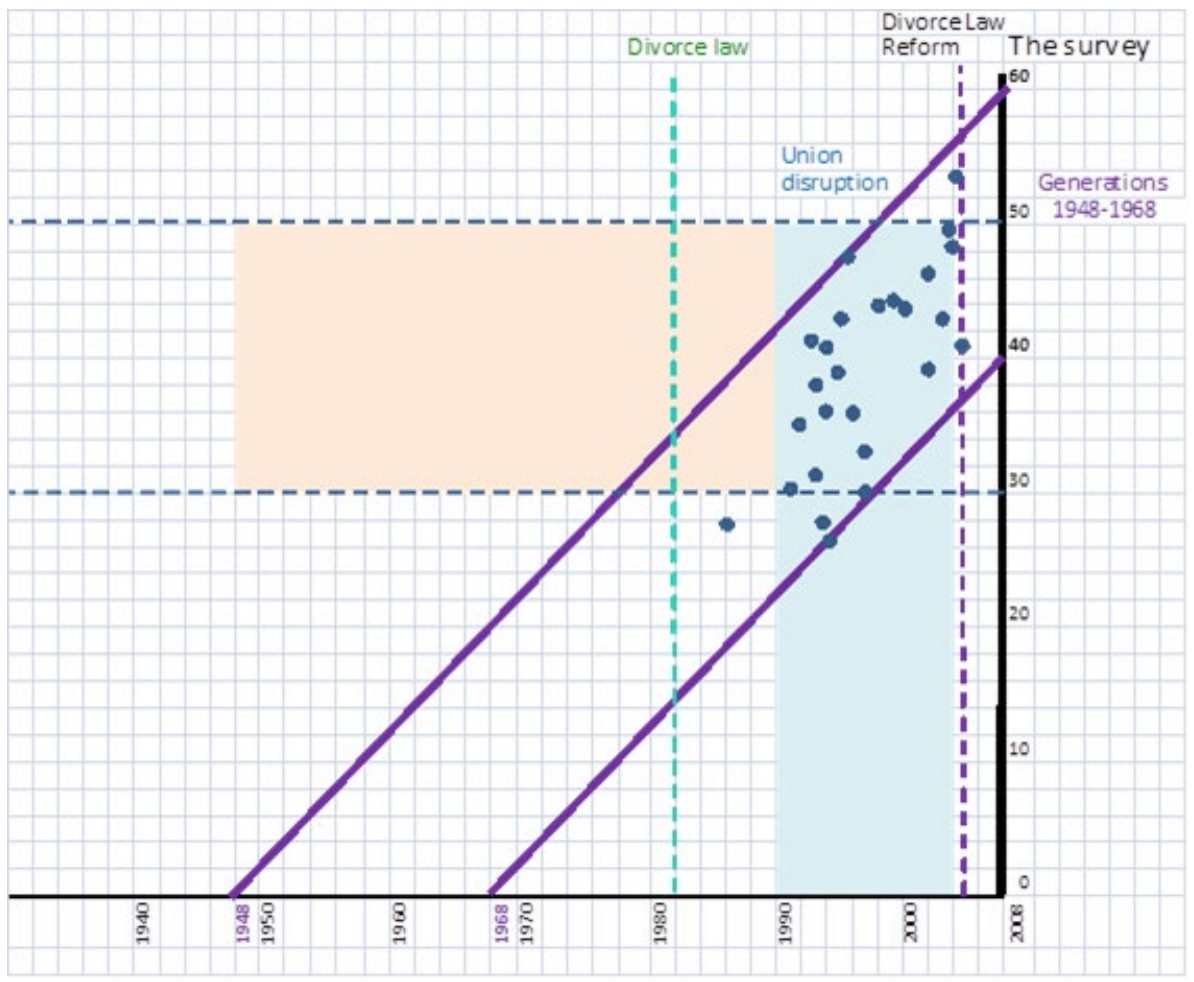

Note: In a Lexis diagram the time reference of events that occur to individuals belonging to different cohorts is represented. In this example calendar year is represented on the $\mathrm{x}$-axis, age on the y-axis and the resulting birth cohort on the z-axis. As is shown, only individuals aged between 40 and 60 (i.e. born between 1948 and 1968) were interviewed, who experienced their first union dissolution between 1990 (except one) and the Divorce Law Reform of 2005.

Source: AUTHOR (2011). 
Figure 2. Example of family configuration. Mimo without stable union.

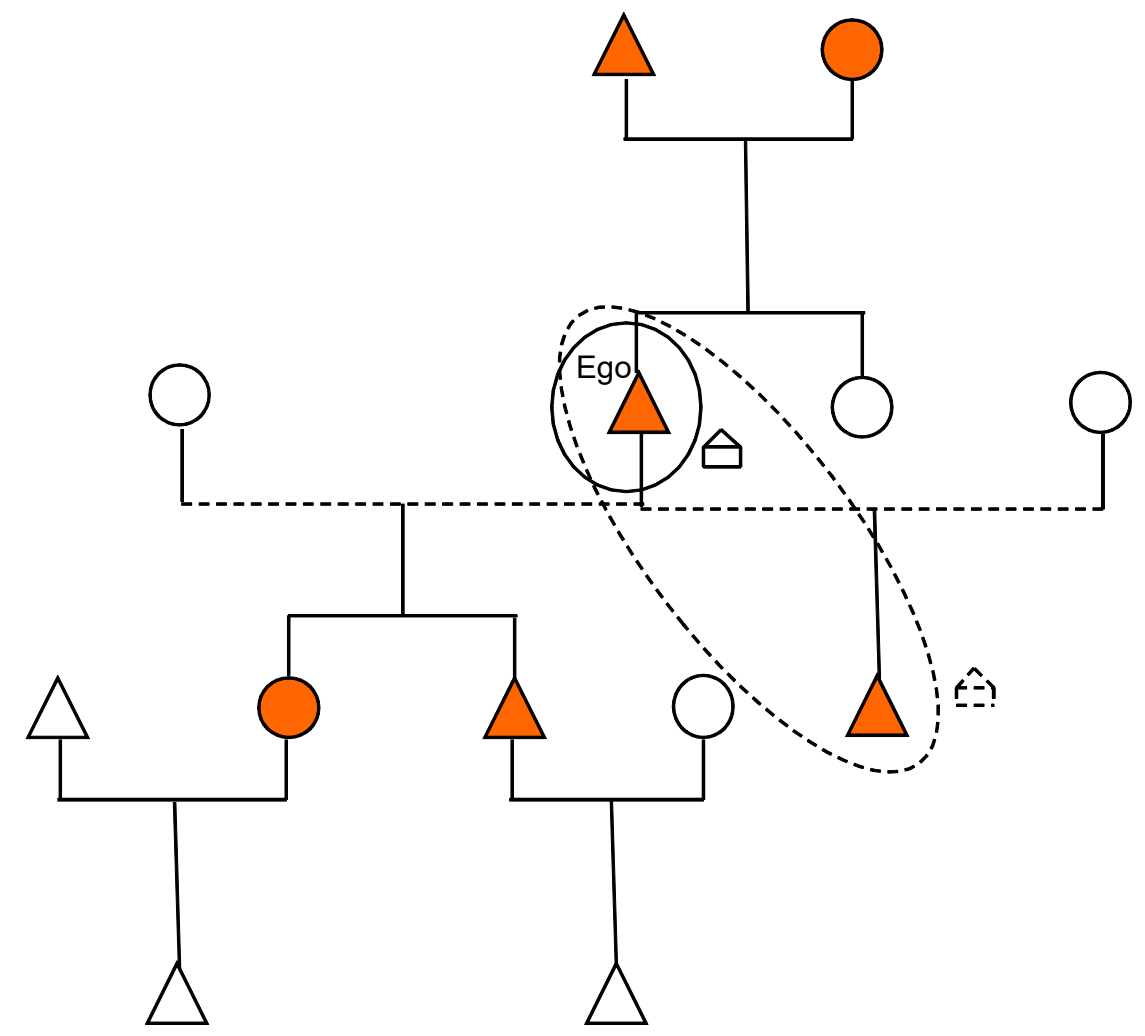

Legend: $\bigcirc$ female $\triangle$ male. Circle and dotted sphere: Ego lives in one-person household but shares it with son during weekends. Colored symbol: what ego considers as his "family", i.e. biological kin only. 
Figure. 3 Example of family configuration. Angela in L.A.T. relationship
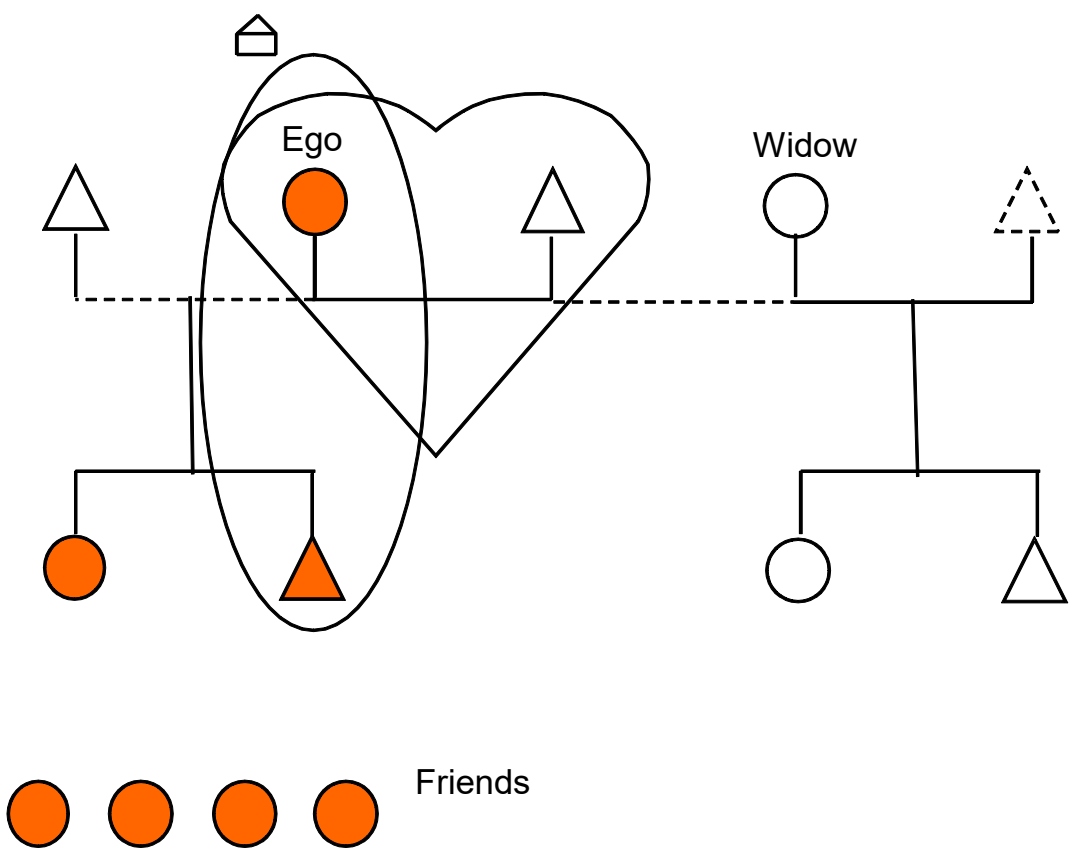

Legend: $\bigcirc$ female $\triangle$ male. Heart: Ego lives in one-person household but is in a L.A.T. relationship. Colored symbol: what ego considers as his "family", i.e. biological kin and close friends. 